\title{
Peran-Peran Kepemimpinan dalam Peningkatan Kinerja di Lembaga Pendidikan Islam
}

\author{
Sandra Hasba \\ Pascasarjana Universitas Halu Oleo \\ Email: Sandra.uho@gmail.com
}

\begin{abstract}
Abstrak
Artikel ini bertujuan memberikan gambaran tentang peranperan kepemimpinan dalam peningkatan kinerja lembaga pendidikan. Pandangan ini didasarkan pada paradigm kepemimpinan transformasional yang menegaskan bahwa kejayaan ataupun kemunduran suatu organisasi sangat ditentukan oleh kepemimpinan. Karenannya dibutuhkan penerapan fungsi-fungsi kepemimpinan dalam rangka kemajuan suatu organisasi. Misi ini juga berlaku pada lembaga pendidikan yang secara terbuka sedang mengalami kondisi yang penuh persaingan. Untuk dapat memenangkan persaingan, maka kinerja perlu ditingkatkan, yang ditopang oleh kepemimpinan yang relevan. Artikel ini menemukan penerapan fungsi-fungsi kepemimpinan yang tepat di Ummushabri, yang dalam kajian ini dibatasi pada tingkat MI. Terlihat jelas bahwa kinerja unggul dari warga sekolah merupakan hasil dari kepemimpinan yang baik.
\end{abstract}

Kata Kunci: Kepemimpinan, Kinerja, Kualitas 


\title{
Leadership Roles in Improving Performance in Islamic Education Institutions
}

\author{
Sandra Hasba \\ Pascasarjana Universitas Halu Oleo \\ Email: Sandra.uho@gmail.com
}

\begin{abstract}
This article aims to provide an overview of leadership roles in improving the performance of educational institutions. This view is based on the transformational leadership paradigm which emphasizes that the success or decline of an organization is largely determined by leadership. Therefore, it is necessary to apply leadership functions in the context of the progress of an organization. This mission also applies to educational institutions that are openly experiencing competitive conditions. To be able to win the competition, performance needs to be improved, which is supported by relevant leadership. This article finds the proper implementation of leadership functions in Ummushabri, which in this study is limited to the MI level. It is clear that the superior performance of school members is the result of good leadership.
\end{abstract}

Keywords: Leadership, Performance, Quality

\section{Pendahuluan}

Kepemimpinan seseorang berperan sebagai penggerak dalam proses kerja sama antar manusia dalam organisasi termasuk sekolah. Kepemimpinan menjadikan suatu organisasi dapat bergerak secara terarah dalam upaya mencapai tujuan yang telah ditetapkan. Kepemimpinan mempengaruhi kepemimpinan untuk menggerakkan baawahannya menjadi taat, hormat, setia, dan mudah bekerja sama" (Usman, 2013). Menurut Covey, Kepemimpinan merupakan inti dari manajemen karena kepemimpinan merupakan motor penggerak dari semua sumber daya (resources) dan alat yang tersedia bagi suatu organisasi". Resources ini digolongkan dua bagian: (1) human resources dan (2) non human resources (Kaswan, 2013). 
Covey mengklasifikasi peran kepemimpinan sebagai berikut, yaitu: peran perintis, peran penyelaras, dan peran pemberdayaan" (Kaswan, 2013). Sedangkan perilaku kepemimpinan, menurut Robbins dapat dibedakan menjadi empat yaitu:

1. Memerintah, pemimpin memberitahu apa dan kapan sesuatu dikerjakan, tidak ada partisipasi dalam pengambilan keputusan.

2. Mendukung, yaitu manjer menjadi sahabat bagi pengawai dan menunjukkan minat kepada mereka.

3. Memudahkan, yaitu pemimpin member saran dan melibatkan pegawai dalam mengambil keputusan.

4. Orientasi prestasi, yaitu pimpinan membagi kontribusi tentang tujuan dan menunjukan kepercayaan bahwa pegawai mampu mencapainya. (Makawimbang, 2012).

Kepemimpinan merupakan faktor penting dalam memberikan pengarahan kepada karyawan apalagi pada saat-saat sekarang ini dimana semua serba terbuka, maka kepemimpinan yang dibutuhkan adalah kemepimpinan yang bisa memberdayakan karyawannya. Kepemimpinan yang bisa menumbuhkan motivasi kerja karyawan adalah kepemimpinan yang bisa menumbuhkan rasa percaya diri para karyawan dalam menjalankan tugasnya masing-masing.

Salah satu tantangan yang cukup berat yang sering harus dihadapi oleh pemimpin adalah bagaimana ia dapat menggerakkan pada bawahannya agar senantiasa mau dan bersedia menggerakkan kemampuannya yang terbaik untuk kepentingan kelompok atau organisasinya. Sering kali kita menjumpai adanya pemimpin yang menggunakan kekuasaannya secara mutlak dengan memerintahkan para bawahannya tanpa memperhatikan keadaan yang ada pada bawahannya. Hal ini jelas akan menimbulkan suatu hubungan yang tidak harmonis dalam organisasi.

Kepala sekolah merupakan salah satu komponen dalam pendidikan yang berpengaruh dalam meningkatkan kinerja pegawai. Kepala sekolah bertanggung jawab atas penyelenggaraan kegiatan pendidikan, administrasi sekolah, pembinaan tenaga lainnya, dan pendayagunaan serta pemeliharaan sarana dan prasarana. Kurang maksimalnya kepala sekolah dalam membina dan membimbing kinerja pegawainya, sehingga masih ada kinerja pegawai yang kurang disiplin dalam bertugas, terlamba datang dan pulang lebih awal. Kondisi seperti itulah yang menjadi permasalahan dilembaga pendidikan (Kasidah, Murniati \& Bahrun, 2017). 
Setiap pegawai dalam organisasi dituntut untuk memberikan kontribusi positif melalui kinerjayang baik, mengingat kinerja organisasi tergantung dari kinerja pegawainya (Gibson, et all, 1995:364). Kinerja adalah tingkat terhadapnya para pegawai mencapai persyaratan pekerjaan secara efesien dan efektif (Simamora, 2006:34). Kinerja pegawai merupakan prestasi kerja, yakni perbandingan hasil kerja yang dapat dilihat secara nyata dengan standar kerja yang telah ditetapkan organisasi.

Kinerja merupakan hasil kerja baik itu secara kualitas maupun kuantitas yang telah dicapai pegawai, dalam menjalankan tugastugasnya sesuai dengan tanggung jawa $b$ yang diberikan organisasi, and hasil kerjanya tersebut disesuaikan dengan hasil kerja yang diharapkan organisasi, melalui kriteria-kriteria atau standarkinerja pegawai yang berlaku dalam organisasi.

Fakta-fakta empirik menunjukkan besarnya pengaruh kepemimpinan terhadap kinerja di berbagai organisasi (Muizu, 2014), (Marpaung, 2014), (Wiranata, 2011), (Marjaya \& Pasaribu, 2019). Pada ranah pendidikan, pengaruh kepemimpinan terhadap kinerja terlihat dalam pengelolaan dinas pendidikan di Kota Bandung. Hasil riset menunjukkan bahwa dimensi-dimensi variable kepemimpinan seperti pengarahan dan dukungan berpengaruh signifikan terhadap kinerja pegawai (Widiastuti, 2014). Demikian pula riset yang dilakukan oleh Setiyati yang menemukan tingginya pengaruh kepemimpinan terhadap kinerja guru di SMKN Gunung Kidul (Setiyati, 2014).

Sementara itu, kepemimpinan pada lembaga pendidikan Islam merupakan faktor utama dalam melakukan inovasi-inovasi (Syahrul, 2015), pengembangan lembaga pendidikan Islam (Fauzi, 2017), dan peningkatan mutu pendidikan (Khikmah, 2008). Kinerja merupakan pengaruh spesifik dari praktik kepemimpinan, seperti ditunjukkan dalam riset di Madrasah Aliyah Pondok Pesantren Al-Ikhlas Ujung Bone, bahwa kepemimpinan memiliki korelasi positif dengan kinerja guru (Paisal, Siraj \& Mania, 2019). Temuan serupa juga dapat dilihat dalam praktik kepemimpinan di Madrasah Ibtidaiyah Negeri di Kabupaten Garut, yang menegaskan bahwa kepemimpinan memiliki pengaruh positif terhadap kinerja guru (Ruhiyat, 2017).

Oleh karena itu, menjalankan peran-peran kepemimpinan sangat penting untuk kemajuan sekolah. Berbagai aspek yang bersinggungan dengan pelaksanaan peran kepemimpinan antara lain: 
pengembangan pendidikan karakter (Mahardika, 2019), peningkatan disiplin guru dan karyawan (Musri, 2020), peningkatan kompetensi guru (Bowo, 2020), dan kinerja guru (Rosya, 2019).

Gagasan di atas, dalam kajian ini dijadikan sebagai cara pandang dalam melihat perkembangan pesat yang dialami oleh Pesantren Metropolitan Ummu Shabri Kendari. Selamat 5 tahun terakhir, pesantren ini terus berbenah dan melakukan lompatanlompatan inovasi. Hasilnya adalah kepercayaan yang tinggi masyarakat Kota Kendari terhadap sekolah ini, dalam bentuk tingginya minat menyekolahkan anak-anak mereka. Tidak hanya lokal, lembaga pendidikan ini telah merambah ke dunia internasional dengan membangun jejaring persekolahan di Asia Tenggara dan Asia. Kinerja unggul yang ditunjukkan itu tentu tidak dapat dipisahkan dari praktik kepemimpinan. Karenanya artikel ini merupakan upaya menggambarkan praktik kepemimpinan dalam peningkatan kinerja di Pesantren Metropolitan Ummu Shabri Kendari. Ada tiga peran kepemimpinan yang akan dikembangkan dalam kajian ini yaitu: peran perintis, peran penyelaras, dan peran pemberdayaan.

\section{Metode}

Penelitian ini dilakukan di Madrasah Ibtidaiyah Ummu Shabri dengan menggunakan pendekatan kualitatif dengan metode naratif, dimana data dikumpulkan melalui proses pengamatan, wawancara dan studi dokumen (Creswell \& Poth, 2016). Analisis data penelitian dilakukan dengan secara bertahap, mulai dari pengumpulan data, reduksi data, penyajian data, hingga penarikan kesimpulan (Miles \& Huberman, 1994). Untuk menjamin keabsahan data, maka peneliti melakukan perpanjangan pengamatan dan peningkatan ketekunan (Moleong, 2006).

\section{Hasil Penelitian}

\section{Menjalankan Peran Sebagai Perintis}

\section{Merumuskan Visi sebagai Gambaran Masa Depan}

Pesantren Metropolitan Ummu Shabri mengangkat visi "Sholeh, Islami, Berprestasi, Populis, Bermasyarakat dan berwawasan lingkungan." Visi tersebut dikembangkan menjadi kerjakerja utama dalam bentuk misi yaitu:

1. Menumbuhkan penghayatan dan pengamalan nilai-nilai Islami dan budaya bangsa sebagai sumber kearifan dalam bertindak 
2. Mengembangkan potensi akademik peserta didik secara optimal sesuai dengan bakat dan minat melalui proses pembelajaran

3. Melaksanakan pembelajaran dan bimbingan secara efektif kepada peserta didik dibidang penguasaan pengetahuan dan teknologi sehingga dapat bersaing dengan Madrasah umum

4. Mengembangkan potensi peserta didik melalui kegiatan olah raga dan seni serta kegiatan ekstra kurikuler untuk memupuk disiplin dan mengembangkan kreativitas

5. Mengoptimalkan potensi warga Madrasah dalam memberi pelayanan kepada siswa dan masyarakat pengguna pendidikan

6. Menerapkan manajemen partisipatif dengan melibatkan warga Madrasah dan stakeholders

7. Memanfaatkan secara maksimal lingkungan Madrasah sebagai sumber belajar, mengamalkan ilmu dan keterampilan

8. Meningkatkan koordinasi dan kerja sama orang tua dan instansi terkait dalam pengembangan Madrasah

9. Mengintensifkan jalinan sinergis dengan SD dan sesama MI Negeri dan Swasta untuk sharing pengembangan Madrasah.

10. Menciptakan lingkungan madrasah yang bersih, religious, santun hijau dan asri (besahaja).

11. Memanfaatkan lingkungan madrasah yang hijau sebagai sarana dan sumber pembelajaran peserta didik.

Secara spesifik misi di atas diturunkan menjadi beberapa tujuan yaitu:

1. Turut bertanggungjawab dalam upaya mencerdaskan masyarakat Indonesia sesuai amanah konstitusi.

2. Membantu masyarakat kota Kendari untuk memudahkan akses memperoleh pelayanan Pendidikan berciri khas islam

3. Menunjukan kepda masyarakat bahwa madrasah mempunyai keunggulan-keunggulan baik di bidang akdemik maupun non akademik.

4. Bekerjasama dengan pemerintah setempat dalam mewujubkan visi dan misinya yang hendak membangun kota Kendari sebagai kota Smart City.

5. Bekerjasama dengan kementerian agama kota Kendari dalam mewujubkan program KEMENAG bersahaja (bersih, religious, santun, hijau dan asri).

\section{Mengenali Kondisi Internal dan Eksternal}


Pelaksanaan peran-peran kepemimpinan di MI Ummusshabri diwujudkan pula dengan mengenali secara komprehensif kekuatan, kelemahan, peluang, dan tantangan. Hasil analisis tersebut dapat dijabarkan sebagai berikut:

Kekuatan:

1. Sekolah MI Ummusshabri Kendari adalah madrasah favorite atau unggulan yang ada di Kota kendari, dengan kualitas pembelajaran yang lebih efektif, sarana dan prasarana yang sangat lengkap dapat menunjang prestasi bagi siswa-siswa yang ada di MI Ummusshabri Kendari . salah satu yang paling menonjol adanya kelas CIBI yang bertaraf Internasioanl dengan fasilitas yang sangat emamdai dan modern. Selain itu tenaga kependidikan ynag dimiliki sangat mumpuni dengan system pengajaran dikelas team teaching yaitu 3 guru yang mengajar secara bersamaan dengan pelajar agama, sains dan BK.

2. Dari pihak yayasan sendiri sangat baik dalam pengelolaan dan menjali mitra untuk pengembangan Madrasah baik itu MI Ummusshbri Kendari.

3. Kerja sama yang baik antara sekolah, komite, dan wali murid, sebagai contoh apabila sekolah mengalami pengambilan kebijakan maka sekolah bersama komite sekolah mengundang para orang tua/wali murid untuk sama-sama memecahkan dan memutuskan apa yang menjadi permasalahan tersebut.

4. Mempunyai tenaga pendidk yang professional.

Kelemahan:

Dalam pelaksanakan tugas administrasi dalam segi pembelajaran dan sarana prasarana yang masih terus dibenahi. Hal ini diakibatkan dengan adanya rencana pembangunan jangka panjang sesuai master plan yang telah dicanangkan.

Peluang:

1. Bersama yayasan meningkatkan prestasi kerja. Dimana dengan adanya hubungan/komunikasi yang baik antara yayasan dengan para guru dalam menjalankan atau mengembangkan visi, misi atau lebih khusus mensejahteraan para guru.

2. Yayasan ini selalu mengikuti perkembangan zaman yang ada terutama pada dunia globalisasi yang makin maju. 
3. Lingkungan sekitar lembaga pendidikan MI Ummusshabri Kendari sangat begitu luas dengan.

Tantangan:

1. Pemanfaatan teknolgi yang harus terus digunakan pada tempatnya.

2. Lingkungan yang sangat luas harus di manfaatkan di baik dengan program-program yang diterapkan.

3. Lokasi yang berada di tengah keramaian kota.

4. Lahan parkir yang belum tertata dengan baik sehingga pada saat pengantar pada pagi hari dan penjuputan pada sore hari sering kali mengabikat macet pada ruas jalan yayasan tersebut.

\section{Membangun Iklim dan Budaya Sekolah}

Budaya yang ditanamkan kepada peserta didik adalah Budaya Islam Akademik ( Senyum, salam, santun dan semangat).

Dari hasil data di atas bahwa untuk mencapai Visi, Misi dan Tujuan Madrasah Ibtidayah Ummusshabri Kendari sudag berupaya semaksimal mungkin dengan malkukan berbagai upaya di semua aspek pembelajaran baik yang mdukung secara sarana dan prasarana maupun finansial. Adapun langkah yang telah di lakukan pihak Madrasah Ibtidayah Ummusshabri Kendari adalah sebagai berikut:

1. Terakreditasi A

2. Sekolah yang berbasis internasional

3. Menyiapkan sarana dan prasaran yang memadai untuk mendukung proses pembelajaran yang berkualitas dan nyaman bagi peserta didik.

4. Tenaga pendidik yang profesional

5. Tenaga kependidikan yang memadai dan professional

6. Menyiapkan dua kelas yaitu kelas CIBI dan Reguler

7. Materi terintegrasi Agama dan Sains

8. Hafalan Al Qur'an dan Doa Harian

9. Mwajibkan lulusan Madrasah Ibtidayah Ummusshabri Kendari hafal jus 30.

10. Menerapkan Budaya Islam Akademik

11. Ruangan dilengkapi AC, LCD, DISPENSER, CCTV, Loker Siswa dan Rak Sepatu diluar kelas.

12. Menyaipkan 12 jenis kegiatan ekstrakulikuler

13. Selalu berupaya berprestasi di tingkat kota, provinsi, nasinal bahkan internasional 
14. Evaluasi dan control melalui system tehnologi / android unth hasil belajar siswa (bagi kelas Cibi)

15. Taman hijua yang memadai

16. Menyipakan karting bagi siswa kelas CIBI

17. Metode pembelajaran yang kreatif dan inovatif

18. Mitra yang banyak

Selain itu, terdapat beberapa catatan dari penulis yang dapat dianggap sebagai kelemahan, yaitu:

1. Belum tersedianya laboratorium

2. Belum tersedia lapangan untuk mata pelajaran olahraga.

3. Sebagian halaman masih belum tertata, akibat dari pihak yayasan masih menbangun

4. Akibat dari pihak yayasan masih menbangun sering kali masih ada titik yang kotor.

Masih seringnya banjir pada titik- titik halaman tertentu.

\section{Menjadi Penyelaras}

\section{Melakukan Konsolidasi Internal untuk Menguatkan Core Business}

Konsolidasi internal adalah keharusan dalam rangka membawa persekolahan Ummu Shabri bersaing di Kota Kendari, nasional, dan internasional. Upaya merambah dunia eksternal tidak dapat dilakukan jika kondisi internal belum kuat. Karena itu, beberapa pilar utama internal mesti dibenahi dan dikuatkan.

Pertama,Tenaga pendidik dan kependidikan pada Madrasah Ibtidayah Ummusshabri Kendari rata-rata berkualifikasi SI dan S2 dimana terbagi dengan jobsheet seperti Guru, Staaf dan Cleaning Servis (Minimal SMA sedejat). Jumlah tenaga pendidik dan kependikan sebanyak 63 orang dengan estimasi guru kelas Reguler dan CIBI 38 orang laki-laki dan 25 orang Perempuan sisanya terbagi pada staff dan cleaning servis.

Kedua, Kurikulum. Berdasarkan UU No. 20 Tahun 2003 kurikulum merupakan seperangkat rencana \& sebuah pengaturan berkaitan dengan tujuan, isi, bahan ajar \& cara yang digunakan sebagai pedoman dalam penyelenggaraan kegiatan pembelajaran untuk mencapai sebuah tujuan pendidikan nasional. Beranjak dari definisi diatas kita dapat melihat penerapan Kurikulum 2013 yang diterapkan Madrasah Ibtidayah Ummusshabri Kendari. Dimana Madrasah Ibtidayah Ummusshabri Kendari meliki 2 kelompok kelas yaitu kelas 
regular dan kelas CIBI (Internasional). Pelaksanaa Kurikulum 2013 sendiri pada kelas reguler dengan system setiap Tema terdiri dari 5 sampai 6 sub tema yang diatur dalam 5 hari kerja atau hari mengajar. Pada kelas CIBI menggunakan metode Tim Teaching. Dimana 3 guru mata pelajaran sekaligus masuk bersamaan di jam yang sama, dengan proses ketika guru agama selesai mangajar, maka guru sains lagi yang maju untuk memberikan pembelajaran sedangkan guru bimbingan konseling (BK) mengamtai dari belakang perkembangan perilaku belajar peserta didik dan ini dilakukan secar kontiniu. Proses aktivitas sekolah dimulai pukul 06.45 dimana di awali beberapa kegiatan yang setiap harinya berbeda. Pada hari:

\begin{tabular}{|l|l|}
\hline Hari & Uraian kegiatan \\
\hline Senin & Sholat dhuha, Tadurus \\
\hline Selasa & Sholat dhuha, Tadurus \\
\hline Rabu & Sholat dhuha, Tadurus dan hafalan \\
\hline Kamis & Sholat dhuha, Tadurus dan senam \\
\hline Jum'at & Sholat dhuha, Tadurus dan manasik \\
\hline
\end{tabular}

Pada sore hari peserta didik mengikuti kegiatan estrakulikuler pilihan seperti, Tahsin, Tahfiz Al- Qur'an (Juz 30), bilingual (Arab dan Inggris), futsal, bulutangkis, tenis meja, tari tradisional, kasidah modern, robotic, olimpiade matematika dan sains, pramuka dan dram band. Khusus pada hari jumat sore peserta didik mengikuti eskul wajib Tahsim awal dan Mahir.

Dalam evaluasi pembelajar sesuai kurikulum 2013 baik reguler maupun CIBI sebanyak 27 kali penialaian selama pertengahan satu semester yang dinilai setiap sub tema yang ada yang dilakukan setiap harimya.ketika dalam satu hari atau sebu tema peserta didik tidak mengikutinya maka akan dikosongkan nilainya Lain halnya pada kelas CIBI yang hasil evaluasi peserta didik di upload pada aplikasi system bernama SISFO (system informasi siswa) CIBI DAN CIBER yang dapat diakses oleh orang tua siswa yang berbasis android. Hal ini juga sangat membantu guru dan orang tua dalam hal kerjasama pengawasan hasil belajar peserta didik.

Setiap kelas baik reguler maupun CIBI itu dilengkapi dengan buku ajar yang memandai. Perbangdingan peaerta didik pada kelas CIBI dengan yiatu 10 banding 1 . Artinya bahwa setiap 10 anak peserta didik pada kelas CIBI dihadapi 1 orang Guru. Persebaran siswa CIBI dapat dilihat pada gambar sebagai berikut: 
Shautut Tarbiyah, Volume 26 Nomor 2, November 2020 Sandra Hasba $\quad$ Peran-Peran Kepemimpinan dalam Peningkatan...

\section{Gambar 1. Persebaran siswa CIBI-MI Ummusshabri}

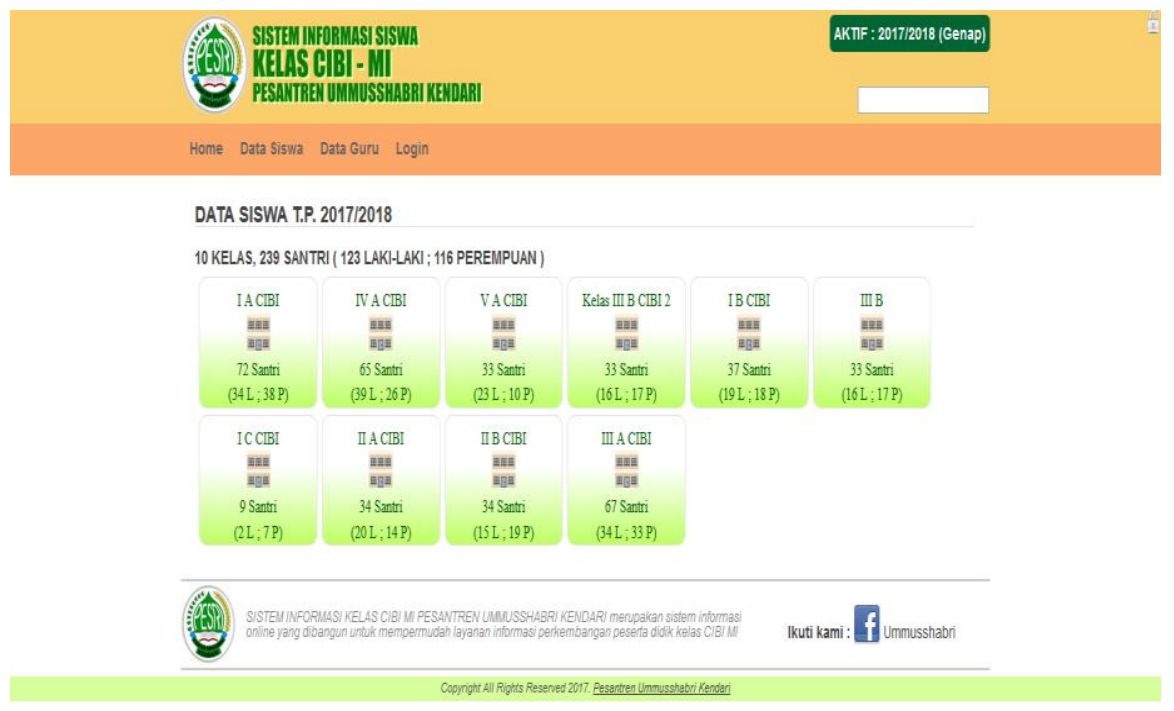

\section{Gambar 2. Sistem Informasi Siwa (SISFO)}

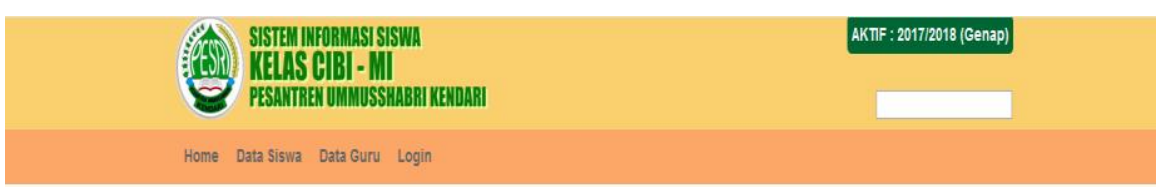

\section{PENGANTAR}

Layanan Sistem Informasi Kelas CIBI MI (Cerdas Intelektual Berbasis Islami) Madrasah Ibidayah Pesantren Ummusshabri Kendari hadir untuk memberikan pelayanan info secara cepat, akurat dan real time tentang perkembangan peserta didik kelas CIBI MI.

PENGUMUMAN PENTING...!

a Untuk memudankan dalam mengetahui informasi perkembangan anak, maka disampaikan kepada Bapaklbu Wail Murid Untuk Mendowload Aplikasi Sisfo Pesri di Playstore.

LOGIN

Pilih Login Sebagai :

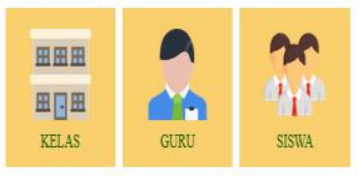

DATA SISFO

Info Jumlah Kelas, Guru dan Siswa

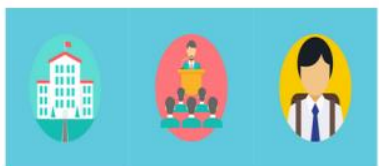




\section{Kelas CIBI Sebagai Keunggulan}

Menggunakan kurikulum 2013, denga system Team Teaching (Guru BK, Agama, Sains). Dalam proses pembelajaran menggunakan sarana yang lebih edukatif dan modern. Menbiasakan menggunakan bilingual (Bahasa arab dan inggris). Selain itu para guru juga melakukan pengembangan dengan pendekatan ESQ dan Fun Game dalam proses pembelajara.

Pada kelas Reguler mempunya lima guru mapel seperti mata pelajaran Bahasa araba, Bahasa inggris, Qur'an Hadis, PGOK dan SPDP. Perbandingan guru pada kelas reguler 1 banding sesuai jumlah siswa per kelas jikalau kelas itu berjumlah 40 oarang per kelas makan perbandingannya $1 / 40$ orang. Pada setiap guru kelas memagang dan megajarkan mata pelajaran Umum seperti Bahasa Indonesia, pkn, ipa dan lain sebagainya.

Pada kelas CIBI dan Reguler sudah menggunakan alat tehnologi sperti laptop dan notebook pada mata pelajaran tertentu.

Pendaftaran atau penerimaan siswa baru di Madrasah Ibtidayah Ummusshabri Kendari lebih cepat dari sekolah lainnya tepatnya pada bulan Januari sampai April dengan tahapan sebagai berikut:

1. Pendaftaran pada 28 januari s.d 29 Maret 2018

2. Tes Masuk pada 30 Maret 2018

3. Pengumuman pada 6 april 2018

4. Daftar ulang pada 7 s.d 15 april 2018

Dalam konteks evaluasi para guru melakukan penilaian setiap hari dan lamgsumg di upload pada akum SISFO yang berbasih Android. Mah hal ini orang tua bisa memamtau langsung perkembangan hasil belajar anaknya memalui aplikasi SISFO. Seketika ada masalah dengan peserta didik para guru melakukan bberapa langkah untuk mememcahkan masalah belajar pada seorang peserta didik dengan cara :

1. Para guru dan orang tua membuat group Whatsapp, kemudia guru menyampaikan masalah tersebut apa yang terjadi pada anaknya.

2. Pihak yayasan sudah membuat aplikasi SISFO untuk memantau langsung hasil belajar anaknya.

3. Para guru sering berdiskusi kepada orang tua secara personal untuk membahsa kesinambungan pembelajaran, kebiasan dan tangka laku baik disekolah maupun dirumah sehingga ada kesinangbungan antara proses pendiidkan di sekolah dengan dirumah. 
4. Dengan adanya diskusi personal dan group anatara para guru dan orang tua peserta didik, maka para guru dapat menjalakan tugasnya dengan baik, baik itu berperan sebagai guru, bapak dan bahkan seoarang sosok ibu (Bapak Guru) pada saat disekolah.

5. Pengawasan keamanan peserta didik dilimpahkan kepada wali kelas masing-masing dan dubantu para guru lainnya serta cleaning servis yang sedah bertugas.

\section{Pelaksanaan Supervisi}

Pada MI Ummusshabri Kendari, supervisi yang dilakukan berbeda dengan sekolah pada umumnya dimana cara yang dilakukan sebagai berikut:

a. Guru yang berstatus Pegawai Negeri Sipil (PNS) di supervise langsung oleh pengawas dari Departmen Agama kota Kendari yang dilaporkan langsung kepada Kepala departemen agama kota Kendari. Adapun yang disupervisi adalah kesiapan bahan mengajar guru seperti perangkap pembelanjaran.

b. Guru Honorer yang melakukan supervise adalah kepala sekolah dimana yang disupervisi sama hal dengan guru PNS.

Proses pembelajaran di kelas, dimana kepala sekolah mengawasi melalui CCTV tiap kelas, sehingga terlihat apa yang dilakukan guru saat pembelajaran dan dapat mengetahui perkembangan belajar menagajar. Ketika ada guru yang secara sumber daya tidak mumpuni setelah dilakukan supervisi dan pengawasan maka dilakukan pembinaan oleh yayasan. Pembinaan yang dilakukan langsung oleh pihak yayasan terkait dengan pengembangan.

\section{Melakukan Pemberdayaan}

\section{Penguatan Hubungan Masyarakat dan Membangun Kemitraan}

Pihak yayasan dan masyarakat kota Kendari khususnya masyarakat sekitar, pihak yayasan memperbelohkan masjid diguanakan untuk sholat berjmaah pada setiap harinya bahkan pada sholat jumat, sholat tarawih dan buka Bersama masyarakat berbondong-bondong ke ummssahbri untuk melaksanakanya serta pada hari raya lainnya yatu sholat id. Selain itu pihak yayasan juga selalu berbagi qurban pada lebaran idul adha.

Pada mitra yayasan, pihak ummussahbri sudah berkejasama berbagai Lembaga swasta dan negeri. Bahkan dalam konteks peserta didik dan tenaga pendidik MI pesri Kendari bermitra beberapa negara 
yaitu, Jepang, Thailand, Malaysia, Singapura dan Turki. Jadi tidak salah kalau pondok pesantren moden ummsshabri kendari khususnya MI Pesri Kendari dikatakan sekolah berbasis internasional.

Kemitraan dan penguatan hubungan masyarakat juga menjadi salah satu strategi pemasaran yang diterapkan oleh Yayasan Ummusshabri. Berbagai event yang melibatkan mitra dan masyarakat secara periodic dilakukan misalnya: jalan santai, Expo Ummushabri pada awal tahun yang rutin dilaksanakan, symposium nasional dan internasional dan sebagainya. Selain itu, pemasaran gencar dilakukan juga melalui media cetak dan Media Sosia.

\section{Mendorong Kemajuan Prestasi Siswa}

Prestasi yang di raih MI Pesri sangatlah banyak mulai dari bidang akademik, kesenian, olahraga dan lain sebagainya. Adapun prestasi MI Pesri pada tahun 2017 yaitu :

1. Juara 1 pada lomba Ki Hajar Dewantara tangka Provinsi Sulawesi Tenggara.

2. Juara 1 Olimpiade Sains IPA se- Kota Kendari

3. Juara 1 lomba pidato se kota Kendari

4. Juara 1 lomba bercerita tingkat Provinsi Sultra

5. Juara 1 majala dinding se kota Kendari

6. Juara 1 putri bunga tingkat provinsi sultra

7. Juara 1 putri bunga cilik sultra

8. Juara 1 lomba gebyar matematika tingkat provinsi

9. Juara II lomba tari Serah se kota Kendari

10. Juara II Olimpiade MTK se kota Kendari

11. Juara II lomba Cerdas Cermat Matematika Tingkat Provinsi

12. Juara III bercerita se kota kendari.

Gambar 3. Deskripsi Temuan

\begin{tabular}{|c|c|c|}
\hline $\mathrm{NO}$ & $\begin{array}{l}\text { DIMENSI PERAN } \\
\text { KEPEMIMPINAN }\end{array}$ & TEMUAN \\
\hline 1 & Peran Perintis & $\begin{array}{l}\text { - Merumuskan visi sebagai } \\
\text { gambaran masa depan } \\
\text { - Mengenali kondisi internal } \\
\text { dan eksternal } \\
\text { - Membangun iklim dan } \\
\text { budaya sekolah }\end{array}$ \\
\hline
\end{tabular}




\begin{tabular}{|c|c|c|}
\hline 2 & Peran Penyelaras & $\begin{array}{l}\text { - Melakukan konsolidasi } \\
\text { internal untuk menguatkan } \\
\text { core business } \\
\text { - Kelas CIBI sebagai unggulan } \\
\text { - Melakukan Supervisi }\end{array}$ \\
\hline 3 & Peran Pemberdayaan & $\begin{array}{l}\text { - Penguatan hubungan } \\
\text { masyarakat dan membangun } \\
\text { kemitraan } \\
\text { - Mendorong kemajuan } \\
\text { prestasi siswa } \\
\end{array}$ \\
\hline
\end{tabular}

\section{Pembahasan}

\section{Peran Kepemimpinan sebagai Perintis}

Setiap komunitas memiliki figure yang menjadi penggerak dan pelopor setiap gerak organisasi. Karenanya, pada diri pemimpin melekat peran sebagai perintis. Sebagai contoh kepemimpinan kiai dalam merintis dan mengembangkan Pondok Pesantren Sabilurrosyad di Kota Malang (Triani, 2016). Peran perintis dalam praktik kepemimpinan dapat diterapkan di berbagai organisasi, baik organisasi profit maupun non profit. Peran perintis dibutuhkan bagi perusahaan yang memiliki latar belakang SDM yang beragam atau multibudaya (Islamiah, Djastuti \& Mas'ud, 2018). Hal ini sejalan dengan ajaran Islam yang menjadi rahmatan lil 'alamin, sehingga melahirkan model kepemimpinan Islam yang merujuk pada karakteristik kepemimpinan Nabi Muhammad SAW (Raharjani \& Mas'ud, 2017).

Peran perintis hanyalah implementasi dari luasnya konsep kepemimpinan yang telah banyak dikemukakan para ahli seperti contoh berikut:

a) Kepemimpinan adalah seni untuk mempengaruhi dan menggerakkan orang-orang untuk memperoleh kepatuhan, kepercayaan, respons, dan kerja sama untuk menyelesaikan tugas (Saibani \& Sumantri, 2014).

b) Kepemimpinan itu adalah kemampuan untuk menanamkan keyakinan dan memperoleh dukungan dari anggota organisasi untuk mencapai tujuan organisasi (Rohaini, 2010). 
c) Menurut Miftah Toha definisi kepemimpinan secara luas adalah meliputi kegiatan atau seni untuk mempengaruhi perilaku orang lain baik perorangan maupun kelompok (Toha, 1986).

d) Menurut Hadari Nawawi, kepemimpinan berarti kemampuan menggerakkan memberikan motivasi dan mempengaruhi orangorang agar bersedia melakukan tindakan-tindakan yang terarah pada pencapaian tujuan melalui keberanian mengambil keputusan tentang kegiatan yang harus dilakukukan (Nawawi, 1998).

Sehingga dapat disimpulkan bahwa kepemimpinan adalah proses kegiatan seseorang yang memiliki kemampuan untuk mempengaruhi, mendorong, mengarahkan, dan menggerakkan individu-individu supaya timbul kerjasama secara teratur dalam upaya mencapai tujuan yang telah ditetapkan bersama. Senada dengan kesimpulan ini, Kartini Kartono menyebutkan bahwa kepemimpinan memiliki unsur-unsur antara lain; kemampuan mempengaruhi orang lain, bawahan atau kelompok, kemapuan mengarahkan tingkah laku bawahan atau orang lain dan untuk mencapai tujuan organisasi atau kelompok (Kartono, 2013).

\section{Peran Kepemimpinan sebagai Penyelaras}

Salah satu isu penting dalam pengelolaan organisasi adalah keragaman, terutama dalam aspek sumber daya manusia. Peran penyelarasan diterapkan dalam rangka menyatukan berbagai sumber daya organisasi untuk mencapai tujuan (Raharjani \& Mas'ud, 2017). Karenanya kompetensi kepemimpinan perlu dimiliki oleh seseorang yang menempati puncak dalam piramida organisasi. Kompetensi kepemimpinan memiliki pengaruh terhadap berbagai variabel organisasi di antaranya: kinerja pegawai (Sumual, 2015), efektifitas kerja (Apriani, 2011), dan komunikasi organisasi (Herlinda, 2019).

Kepemimpinan merupakan salah satu dimensi kompetensi yang sangat menentukan terhadap kinerja atau keberhasilan oragnisasi. Esensi pokok kepemimpinan adalah cara untuk memengaruhi orang lain agar menjadi efektif tentu setiap orang bisa berbeda dalam melakukan. Kepemimpinan merupakan seni, karena pendekatan setiap orang dalam memimpin orang dapat berbeda tergantung karakteristik pemimpin, karakteristik tugas maupun karakteristik orang yang dipimpinnya. Armstrong (2003) menyatakan kepemimpinan adalah proses memberi inspirasi kepada semua karyawan agar bekerja sebaik-baiknya untuk mencapai hasil yang 
diharapkan. Kepemimpinan adalah cara mengajak karyawan agar bertindak benar, mencapai komitmen dan memotivasikan mereka untuk mencapai tujuan bersama (Sudarmanto, 2009:133). Kepemimpinan menurut Anoraga (Anoraga, 2003:3) diartikan sebagai kemampuan seseorang untuk dapat mempengaruhi orang lain, melalui komunikasi baik secara langsung maupun tidak langsung denagn maksud untuk menggerakkan orang-orang tersebut agar dengan penuh pengertian, kesadaran dan senang hati bersedia mengikuti kehendakkehendak pemimpin itu.

\section{Peran Kepemimpinan dalam Pemberdayaan}

Kompetensi sosial merupakan keharusan bagi pemimpin. Hal ini menjadi modal dasar untuk dapat membangun keterikatan dengan warga organisasi. Dalam kehidupan bermasyarakat, pemberdayaan hanya dapat terjadi jika terdapat peran pemimpin (Sulaeman, Murti \& Waryana, 2015). Kepemimpinan yang berbasis pada nilai-nilai religious dalam memberdayakan dimensi psikologis pengikut dalam rangka membangun keterikatan kerja (Widiasih, 2017). Demikian pula pada lembaga pendidikan, peran pemberdayaan dilakukan dalam kerangka edukasi warga sekolah (Arbain, 2018).

Kepemimpinan menurut DuBru (DuBru, 2005:3) adalah upaya mempengaruhi banyak orang melalui komunikasi untuk mencapai tujuan, cara mempengaruhi orang dengan petunjuk atau perintah, tindakan yang menyebabkan orang lain bertindak atau merespons dan menimbulkan perubahan positif, kekuatan dinamis penting yang memotivasi dan mengkoordinasikan organisasi dalam rangka mencapai tujuan, kemampuan untuk menciptakan untuk rasa percaya diri dan dukungan diantara bawahan agar tujuan organisasional dapat tercapai. (Brahmasari \& Suprayetno, 2008:126) berdasarkan pengertian kepemimpinan dari beberapa pendapat ahli diatas, dapat disimpulkan bahwa kepemimpinan erat kaitannya dengan kemampuan seseorang untuk dapat mempengaruhi orang lain agar bekerja sesuai dengan tujuan yang diharapkan.

Kepemimpinan diartikan sebagai kemampuan dan keterampilan seseorang yang menduduki jabatan sebagai pimpinan satuan kerja untuk mempengaruhi perilaku orang lain, terutama bawahannya, untuk berfikir dan bertindak sedemikian rupa sehingga melalui perilaku yang positif ia memberikan sumbangan nyata dalam pencapaian tujuan sekolah. Peran pemimpin sebagai model dengan 
memberikan "rumus sederhana", yaitu model merupakan perpaduan antara karakter dan kompetensi. Karakter adalah diri kita sebagai pribadi, sedangkan kompetensi adalah apa yang bisa kita lakukan (Rivai, 2009).

Wursanto (2002:197) menyatakan teori kepemimpinan adalah bagaimana seseorang menjadi pemimpin atau bagaimana timbulnya seorang pemimpin. Beberapa teori tentang kepemimpinan yaitu:

a. Teori kelebihan

Teori ini beranggapan bahwa seseorang akan menjadi pemimpin apabila ia memiliki kelebihan dari para penggikutnya. Pada dasarnya kelebihan yang harus dimiliki oleh seorang pemimpin mencakup 3 hal yaitu kelebihan ratio, kelebihan rohaniah, dan kelebihan badaniah.

b. Teori sifat

Teori ini menyatakan bahwa seseorang dapat menjadi pemimpin yang baik apabila memiliki sifat-sifat yang positif sehingga para pengikutnya dapat menjadi pengikut yang baik, sifat-sifat kepemimpinan yang umum misalnya besifat adil, suka melindungi, penuh rasa percaya diri, penuh inisiatif, mempunyai daya tarik, energik, persuasif, komunikatif dan kreatif.

c. Teori keturunan

Menurut teori ini, seseorang menjadi pemimpin karena keturunan atau warisan, karena orang tuanya seorang pemimpin maka anaknya otomatis akan menjadi pemimpin menggantikan orang tuanya.

d. Teori Kharismatik

Teori ini menyatakan bahwa seseorang menjadi pemimpin karena orang tersebut mempunyai kharisma (pengaruh yang sangat besar). Pemimpin ini biasanyamemiliki daya tarik, kewibawaan dan pengaruh yang sangat besar.

e. Teori Bakat

Teori ini disebut juga teori ekologis, yang berpendapat bahwa pemimpin lahir karena bakatnya. Ia menjadi pemimpin karena memang mempunyai bakat untuk menjadi pemimpin. Bakat kepemimpinan harus dikembangkan, misalnya dengan memberi kesempatan orang tersebut menduduki suatu jabatan.

f. Teori Sosial

Teori ini beranggapan pada dasarnya setiap orang dapat menjadi pemimpin. Setiap orang mempunyai bakat untuk menjadi 
pemimpin asal dia diberi kesempatan. Setiap orang dapat dididik menjadi pemimpin karena masalah kepemimpinan dapat dipelajari, baik melalui pendidikan formal maupun pengalaman praktek.

\section{Kepemimpinan dan Perbaikan Kinerja}

Salah satu sifat khas dari eksistensi kepemimpinan adalah kemampuan membuat perbedaan (De Vries, 1996). Kemampuan membuat perbedaan disebabkan oleh semangat untuk terus berubah mengikuti perkembangan zaman. Karenanya menciptakan perbedaan dilakukan oleh para pemimpin yang pro perubahan (Keller, 1995). Demikian pula bagi pemimpin sekolah, semangat membuat perbedaan akan memengaruhi prestasi siswa (ten Bruggencate, Luyten, Scheerens \& Sleegers, 2012).

Setiap pegawai dalam organisasi dituntut untuk memberikan kontribusi positif melalui kinerja yang baik, mengingat kinerja organisasi tergantung pada kinerja pegawainya (Gibson, et all, 1995:364). Kinerja adalah tingkat terhadapnya para pegawai mencapai persyaratan pekerjaan secara efisien dan efektif (Simamora, 2006:34). kinerja pegawai merupakan prestasi kerja, yakni perbandingan antara hasil kerja yang dapat dilihat secara nyata dengan standar kerja yang telah ditetapkan organisasi. Kemudian Robbins (2008) mendefinisikan kinerja yaitu suatu hasil yang dicapai oleh pegawai dalam pekerjaanya menurut kriteria tertentu yang berlaku untuk suatu pekerjaan.

Lalu Mangkunegara (2005:67) kinerja ialah hasil kerja baik secara kualitas maupun kuantitas yang dicapai oleh seorang pegawai dalam melakukan tugas sesuai dengan tanggung jawab yang diberikan kepadanya. Sedangkan Rivai (2009:532) kinerja diartikan kesediaan seseorang atau kelompok orang untuk melakukan suatu kegiatan, dan menyempurnakannya sesuai tanggung jawabnya dengan hasil seperti yang diharapkan.

Berdasarkan pengertian-pengertian kinerja dari beberapa pendapat diatas, dapat disimpulkan bahwa kinerja merupakan hasil kerja baik itu secara kualitas maupun kuantitas yang telah dicapai pegawai, dalam menjalankan tugas-tugasnya sesuai dengan tanggung jawab yang diberikan organisasi, dan hasil kerjany tersebut disesuaikan dengan hasil kerja yang diharapkan organisasi, melalui kriteria-kriteria atau standar kinerja pegawai yang berlaku dalam organisasi. Adapun tujuan kinerja pegawai menurut Rivai (2009:549): 
1. Untuk perbaikan hasil kinerja pegawai, baik secara kualitas ataupun kuantitas.

2. Memberikan pengetahuan baru dimana akan membantu pegawai dalam memecahan masalah yang kompleks, dengan serangkaian aktifitas yang terbatas dan teratur, melalui tugas sesuai tanggung jawab yang diberikan organisasi. Memperbaiki hubungan antar personal pegawai dalam aktivitas kerja dalam organisasi.

Kinerja pegawai dipengaruhi oleh berbagai faktor (Gibson, et all, 1995:375), antara lain:

1. Faktor individu, yaitu kemampuan dan keterampilan (mental dan fisik), latar belakang (pengalaman, keluarga, dst), dan demografis (umur, asal usul, dll).

2. Faktor organisasi, adalah sumber daya, kepemimpinan, imbalan (kompensasi), struktur organisasi, dan diskripsi pekerjaan (job description).

3. Faktor psikologis, ialah persepsi, sikap, kepribadian, pola belajar, dan motivasi.

Dalam suatu organisasi pegawai dituntut untuk mampu menunjukkan kinerja yang produktif, untuk itu pegawai harus memiliki ciri individu yang produktif. Ciri ini menurut Sedarmayanti (2001:51) harus ditumbuhkan dalam diri pegawai untuk meningkatkan kinerjanya. Adapun ciri-ciri atau karakteristik dari individu yang produktif antara lain:

1. Kepercayaan diri

2. Rasa tanggung jawab

3. Rasa cinta terhadap pekerjaan

4. Pandangan ke depan

5. Mampu menyelesaikan persoalan

6. Penyesuaian diri terhadap lingkungan yang berubah

7. Memberi kontribusi yang positif terhadap lingkungan

8. Kekuatan untuk menunjukkan potensi diri

Kinerja pegawai secara objektif dan akurat dapat dievaluasi melalui tolak ukur tingkat kinerja. Pengukuran tersebut berarti memberi kesempatan bagi para pegawai untuk mengetahui tingkat kinerja mereka. Memudahkan pengkajian kinerja pegawai, lebih lanjut dalam tinjauan Manajemen Sumber Daya Manusia dan Produktivitas Kerja, Mitchel mengemukakan indikator-indikator kinerja yaitu sebagai berikut:

1. Kualitas kerja 
2. Ketetapan waktu

3. Inisiatif

4. Kemampuan

5. Komunikasi. (Sedarmayanti, 2001:51).

\section{Kesimpulan dan Implikasi}

Kepemimpinan merupakan syarat dari kehidupan sosial, sehingga menjadi kebutuhan mendesak masyarakat di setiap saat. Lembaga pendidikan sedang memasuki masa kompetisi yang sangat kuat, terlihat dan tidak terlihat. Dengan demikian, kehadiran pemimpin yang dapat memahami semangat zaman sangat diperlukan, yaitu figure yang memiliki gagasan dan dapat menerapkannya dalam kegiatan managerial, serta ketajaman visi dan kepekaan terhadap perubahan lingkungan organisasi yang sangat cepat. Kehadiran pemimpinan yang demikian akan meningkatkan kinerja lembaga pendidikan secara keseluruhan.

Kajian ini merekomendasikan perlunya kajian lebih lanjut tentang kompetensi kepemimpinan dalam merumuskan strategi pengembangan lembaga pendidikan Islam di era 4.0.

\section{Daftar Pustaka}

Apriani, F. (2011). Pengaruh Kompetensi, Motivasi, dan Kepemimpinan terhadap Efektivitas Kerja. Bisnis \& Birokrasi Journal, 16(1).

Arbain, M. (2018). Peran Kepemimpinan dalam Pemberdayaan Tenaga Kependidikan. Misykat Al-Anwar, 29(2).

Bowo, B. (2020). PERAN KEPEMIMPINAN KEPALA SEKOLAH SEBAGAI SUPERVISOR DALAM MENINGKATKAN KOMPETENSI GURU DI SMA NEGERI 1 NGRONGGOT KABUPATEN NGANJUK TAHUN 2020. Dharma Pendidikan, 15(2), 93-106.

Creswell, J. W., \& Poth, C. N. (2016). Qualitative inquiry and research design: Choosing among five approaches. Sage publications.

De Vries, M. K. (1996). Leaders who make a difference. European Management Journal, 14(5), 486-493. 
Fauzi, A. (2017). Kepemimpinan Kepala Madrasah Dalam Mengembangkan Lembaga Pendidikan Islam. Nidhomul Haq: Jurnal Manajemen Pendidikan Islam, 2(2), 53-64.

Herlinda, H. (2019). KOMPETENSI KEPEMIMPINAN GLOBAL DALAM KONTEKS KOMUNIKASI ORGANISASI. Mediakom: Jurnal Ilmu Komunikasi, 3(1), 38-50.

Islamiah, M. H., Djastuti, I., \& Mas'ud, F. (2018). KEPEMIMPINAN MULTIBUDAYA (Studi Fenomenologi Pada PT. Terminal Petikemas Surabaya). SEGMEN Jurnal Manajemen dan Bisnis, 14(1).

Kartini Kartono. (2013). Pemimpin Dan Kepemimpinan. Jakarta: Rajawali Press, 2013.

Kasidah, Murniati dan Bahrun, Kepemimpinan kepala sekolah dalam meningkatkan kinerja guru pada sekolah dasar luar biasa negeri banda aceh, Jurnal Magister Administrasi Pendidikan Pascasarjana Uneversitas Syiah Kuala, Volume 5, No. 3, Agustus $2017-128$

Keller, R. T. (1995). 'Transformational'leaders make a difference. Research-technology management, 38(3), 41-44.

Khikmah, N. (2008). Kepemimpinan kepala madrasah dalam meningkatkan mutu pendidikan MAN Pasuruan (Doctoral dissertation, Universitas Negeri Islam Maulana Malik Ibrahim).

MAHARDIKA, E. (2019). PERAN KEPEMIMPINAN KEPALA MADRASAH ALIYAH DALAM MENGEMBANGKAN PENDIDIKAN KARAKTER DI PONDOK PESANTREN TERPADU USHULUDDIN LAMPUNG SELATAN (Doctoral dissertation, UIN Raden Intan Lampung).

Marjaya, I., \& Pasaribu, F. (2019). Pengaruh Kepemimpinan, Motivasi, Dan Pelatihan Terhadap Kinerja Pegawai. Maneggio: Jurnal Ilmiah Magister Manajemen, 2(1), 129147.

Marpaung, M. (2014). Pengaruh kepemimpinan dan Team work Terhadap kinerja karyawan Di koperasi sekjen kemdikbud senayan jakarta. Jurnal Ilmiah WIDYA, 1(1).

Miles, M. B., \& Huberman, A. M. (1994). Qualitative Data Analysis.(terjemahan Tjetjep Rohendi Rohidi).

Moleong, L. J. (2006). Metode penelitian kualitatif edisi revisi. Bandung: Remaja Rosdakarya. 
Muizu, W. O. Z. (2014). Pengaruh Kepemimpinan Terhadap Kinerja Karyawan. PEKBIS (Jurnal Pendidikan Ekonomi Dan Bisnis), 6(1), 1-13.

Musri, M. (2020). PERAN KEPEMIMPINAN KEPALA SEKOLAH TERHADAP KEDISIPLINAN GURU DAN KARYAWAN DI SMP NEGERI 8 PADANG. Jurnal Ilmiah Ekotrans \& Erudisi, 1(1), 33-45.

Nawawi, Hadari. (1998). Administrasi Pendidikan, Jakarta: Haji Masagung.

Paizal, I., Siraj, A., \& Mania, S. (2019). Hubungan Gaya Kepemimpinan Kepala Madrasah dengan Kinerja Guru di Madrasah Aliyah Pondok Pesantren Al-Ikhlas Ujung Bone. Jurnal Pendidikan Agama Islam Al-Thariqah, 4(1), 21-37.

Raharjani, D. S., \& Mas'ud, F. (2017). PRAKTIK KEPEMIMPINAN ISLAM (Studi Kasus pada Kepala Bagian Non Medis Rumah Sakit Roemani Muhammadiyah Semarang). Diponegoro Journal of Management, 6(3), 200-212.

Rivai, Veitzhal. (2009). Education Management Analisis Teori dan Praktik. Jakarta: Rajawali Pers,2009.

Rohaini. (2014). Kepemimpinan Madrasah Transformatif. Yogyakarta: Lkis

Rosya, N. N. (2019). PERAN KEPEMIMPINAN KEPALA SEKOLAH DALAM MENINGKATKAN KINERJA GURU DI SMA ISLAM CENDIKIA BANDAR LAMPUNG (Doctoral dissertation, UIN Raden Intan Lampung).

Ruhiyat, M. Y. (2017). Pengaruh Kepemimpinan Kepala Madrasah dan Supervisi Pengawas Madrasah terhadap Kinerja Guru untuk Mewujudkan Mutu Pendidikan di Madrasah. Jurnal Pendidikan UNIGA, 11(1), 26-37.

Saibani, Beni Ahmad dan Ii Sumantri. (2014). Kepemimpinan, Bandung: Pustaka Setia, 2014

Setiyati, S. (2014). Pengaruh kepemimpinan kepala sekolah, motivasi Kerja, dan budaya sekolah terhadap kinerja guru. Jurnal Pendidikan Teknologi dan Kejuruan, 22(2), 200-206.

Sulaeman, E. S., Murti, B., \& Waryana, W. (2015). Peran Kepemimpinan, Modal Sosial, Akses Informasi serta Petugas dan Fasilitator Kesehatan dalam Pemberdayaan Masyarakat Bidang Kesehatan. Kesmas: National Public Health Journal, 9(4), 353-361. 
Sumual, T. E. (2015). Pengaruh Kompetensi Kepemimpinan, Budaya Organisasi terhadap Kinerja Pegawai di Universitas Negeri Manado. MIMBAR: Jurnal Sosial dan Pembangunan, 31(1), 71-80.

Syahrul, S. (2015). Kepemimpinan dan Inovasi Lembaga Pendidikan (Pengalaman Pondok Gontor VII Putra Sulawesi Tenggara). Al-TA'DIB: Jurnal Kajian Ilmu Kependidikan, 8(1), 82-100.

ten Bruggencate, G., Luyten, H., Scheerens, J., \& Sleegers, P. (2012). Modeling the influence of school leaders on student achievement: how can school leaders make a difference?. Educational administration quarterly, 48(4), 699-732.

Toha, Miftah. (1986). Perilaku Organisasi. Jakarta: CV. Rajawali.

Triani, N. (2016). Kepemimpinan Kiai dalam Merintis dan Mengembangkan Pondok Pesantren Sabilurrosyad Kota Malang. SKRIPSI Jurusan Administrasi Pendidikan-Fakultas Ilmu Pendidikan UM.

Wiranata, A. A. (2011). Pengaruh Kepemimpinan Terhadap Kinerja dan Stres Karyawan (studi kasus: CV. Mertanadi). Jurnal Ilmiah Teknik Sipil.

Widiasih, P. A. (2017). Peran kepemimpinan profetik dan pemberdayaan psikologis dalam membangun keterikatan kerja karyawan. Jurnal Ilmiah Penelitian Psikologi: Kajian Empiris \& Non-Empiris, 3(1), 31-41.

Widiastuti, I. (2014). Pengaruh kepemimpinan terhadap kinerja pegawai di dinas pendidikan kota bandung (Doctoral dissertation). 